\title{
Photocatalytic Efficiency of Mill Scale for the Degradation of Textile Dye by Photo Fenton and Photo-Ferrioxalate System Under UV and Sunlight
}

\author{
Sheik Md. Kazi Nazrul Islam ${ }^{1}$, ASW Kurny ${ }^{2}$, Fahmida Gulshan ${ }^{2, *}$ \\ University of Information Technology and Sciences (UITS), Dhaka-1212, Bangladesh \\ ${ }^{2}$ Bangladesh University of Engineering and Technology (BUET), Dhaka-1000, Bangladesh \\ *Corresponding Author: fahmidagulshan@mme.buet.ac.bd
}

Copyright @ 2013 Horizon Research Publishing All rights reserved.

\begin{abstract}
The aim of the study was to investigate the photocatalytic efficiency of mill scale (waste iron oxide collected from local steel plants) for the degradation of textile dyes. The photodegradation on methylene blue (MB) in natural environment with co-existence of mill scale and oxalic acid/ $\mathrm{H}_{2} \mathrm{O}_{2}$ under UV or sunlight were studied. Some effecting factors such as mill scale content, oxalate ion, $\mathrm{H}_{2} \mathrm{O}_{2}$ and $\mathrm{MB}$ concentration were also investigated. Dye decomposition rate was found to increase with an increase in the amount of mill, reached a maximum and then decreased with increasing mill scale concentration. The decomposition rate decreased with increasing dye concentration. Faster dye degradation was observed by mill scale $/ \mathrm{H}_{2} \mathrm{O}_{2}$ than with mill scale/oxalic acid system. Photocatalytic performance of mill scale (a solid waste) was found as an interesting alternative for the degradation of dyes (liquid waste).
\end{abstract}

Keywords Advanced Oxidation Processes (AOPS), Photo-Fenton, Fenton, Methylene Blue, Degradation

\section{Introduction}

The textile dyeing industries of Bangladesh generate large amount of effluents, sewage sludge and solid waste materials everyday which are being directly discharged into the surrounding channel, agricultural fields, irrigation channels, surface water and these finally enter into river. The presence of dyes in surface and subsurface water is making them not only aesthetically objectionable but also causes many water borne diseases, viz. mucous membrane, dermatitis, perforation of nasal septum and severe irritation of respiratory tract. Various options have been being employed to treat such wastes. These include chemical treatment such as chlorination and ozonation [1, 2], electrochemical treatment [3], physical treatment such as adsorption by activated carbon and membranes $[4,5]$, biological treatment and advanced oxidation processes (AOPs) [6].
AOPs have attracted wide interests in wastewater treatment since the 1990s. In principle, AOPs are based on the generation of hydroxyl radicals in water, which are highly reactive and nonselective oxidants being able to oxidize organic compounds particularly unsaturated organic compounds such as azo dyes. Among AOPs, two of the most important processes to generate hydroxyl radicals are using the photo-Fenton and photo-ferioxalate $\left(\mathrm{Fe}^{2+} / \mathrm{H}_{2} \mathrm{O}_{2} / \mathrm{UV}\right.$ and $\mathrm{Fe}^{2+} / \mathrm{OA} / \mathrm{UV}$ ) systems [7]. The photo-Fenton process starts with the combination of $\mathrm{H}_{2} \mathrm{O}_{2}$ with $\mathrm{Fe}^{2+}$ or $\mathrm{Fe}^{3+}$ shown in below. The reactions involved are briefly described as:

$$
\begin{array}{r}
\mathrm{Fe}^{2+}+\mathrm{H}_{2} \mathrm{O}_{2} \rightarrow \mathrm{Fe}^{3+}+{ }^{-} \mathrm{OH}+{ }^{\bullet} \mathrm{OH} \\
\mathrm{Fe}^{3+}+{ }^{-} \mathrm{OH} \rightarrow \mathrm{Fe}(\mathrm{OH})^{2+} \leftarrow \mathrm{Fe}^{2+}+{ }^{\bullet} \mathrm{OH} \\
\mathrm{Fe}(\mathrm{OH})^{2+}+\mathrm{h} v \rightarrow^{\cdot} \mathrm{OH}+\mathrm{Fe}^{2+}
\end{array}
$$

The reaction process starts again using photo generated $\mathrm{Fe}^{2+}$ [8]. During the photochemical reaction of $\mathrm{Fe}$ (III)-oxalate complexes under illumination by $\mathrm{UV}$ and/or visible light, superoxides hydroperoxiyl radicals $\left({ }^{\circ} \mathrm{O}_{2}{ }^{-} /{ }^{\circ} \mathrm{O}_{2} \mathrm{H}\right)$ [Eqs (5) - (9)] are formed as the key intermediates. $\mathrm{H}_{2} \mathrm{O}_{2}$ thought to be formed from ${ }^{\circ} \mathrm{O}_{2}{ }^{-} / \mathrm{O}_{2} \mathrm{H}$ [Eqs. (10) and (11)] participates in a classical Fenton reaction with $\mathrm{Fe}$ (II), formed by photo-reduction of $\mathrm{Fe}$ (III), producing ${ }^{\circ} \mathrm{OH}$ [Eq. (12)] [9]:

$$
\begin{gathered}
\text { Iron oxide }+\mathrm{nH}_{2} \mathrm{C}_{2} \mathrm{O}_{4} \rightarrow\left[\mathrm{Fe}(\mathrm{III})\left(\mathrm{C}_{2} \mathrm{O}_{4}\right)_{\mathrm{n}}\right]^{(2 \mathrm{n}-3)} \\
{\left[\mathrm{Fe}(\mathrm{III})\left(\mathrm{C}_{2} \mathrm{O}_{4}\right)_{\mathrm{n}}\right]^{(2 \mathrm{n}-3)-}+\mathrm{h} v \rightarrow\left[\mathrm{Fe}(\mathrm{III})\left(\mathrm{C}_{2} \mathrm{O}_{4}\right)_{2}\right]^{2}+{ }^{\bullet}\left(\mathrm{C}_{2} \mathrm{O}_{4}\right)(5)} \\
{\left[\mathrm{Fe}(\mathrm{III})\left(\mathrm{C}_{2} \mathrm{O}_{4}\right)_{\mathrm{n}}\right]^{(3-2 \mathrm{n})-}+\mathrm{h} \nu \rightarrow} \\
{\left[\mathrm{Fe}(\mathrm{II})\left(\mathrm{C}_{2} \mathrm{O}_{4}\right)_{(\mathrm{n}-1)}\right]^{(4-2 \mathrm{n})}+{ }^{\bullet}\left(\mathrm{C}_{2} \mathrm{O}_{4}\right)^{-}} \\
\cdot\left(\mathrm{C}_{2} \mathrm{O}_{4}\right)^{-} \rightarrow \mathrm{CO}_{2}+\cdot\left(\mathrm{CO}_{2}\right) \\
\cdot\left(\mathrm{CO}_{2}\right)^{-}+\mathrm{O}_{2} \rightarrow \mathrm{CO}_{2}+{ }^{\cdot} \mathrm{O}_{2}^{-} \\
\cdot \mathrm{O}_{2}^{-}+\mathrm{H}^{+} \rightarrow{ }^{\circ} \mathrm{O}_{2} \mathrm{H}
\end{gathered}
$$


Semiconductor- photocatalysis evokes interest because of its potential to utilize natural sunlight, and studies on semiconductor- catalyzed environmental remediation using artificial UV light are numerous. $\mathrm{TiO}_{2}, \mathrm{ZrO}_{2}, \mathrm{~V}_{2} \mathrm{O}_{5}, \mathrm{MoO}_{3}$, $\mathrm{Fe}_{2} \mathrm{O}_{3}, \mathrm{Co}_{3} \mathrm{O}_{4}, \mathrm{CuO}, \mathrm{ZnO}, \mathrm{ZnS}, \mathrm{CdO}, \mathrm{CdS}, \mathrm{Al}_{2} \mathrm{O}_{3}, \mathrm{SnO}_{2}$, $\mathrm{PbO}, \mathrm{Pb}_{2} \mathrm{O}_{3}, \mathrm{PbO}_{2}, \mathrm{Sb}_{2} \mathrm{O}_{3}, \mathrm{Bi}_{2} \mathrm{O}_{3}, \mathrm{La}_{2} \mathrm{O}_{3}, \mathrm{CeO}_{2}, \mathrm{Pr}_{6} \mathrm{O}_{11}$, and $\mathrm{Eu}_{2} \mathrm{O}_{3}$ are employed as photocatalyst [10-13]. In the present study we report the photocatalytic efficiency of cheap, commercially available metal oxide-mill scale (waste iron oxide generated in steel re-rolling plants) under natural sunlight and UV light. Methylene Blue(MB) is selected as model pollutant which is extensively used in textile, foodstuff and pharmaceutical industries as a thiazine dye. The optimal conditions of experimental parameters for the removal of MB have also been determined.

\section{Experimental}

\subsection{Samples}

Mill scale was collected from local steel industries. The molecular structure and other properties of MB are shown in table 1. All the chemicals were used without further purification.

Table 1. Properties of MB

\begin{tabular}{|c|c|c|}
\hline \multicolumn{3}{|c|}{ Methylene Blue (MB) } \\
\hline Nature & Cationic dye \\
\hline $\begin{array}{c}\lambda_{\max }(\mathrm{nm}) \\
\begin{array}{c}\text { weight } \\
(\mathrm{g} / \mathrm{mol})\end{array}\end{array}$ & 664 \\
\hline $\begin{array}{c}\text { Molecular } \\
\text { structure }\end{array}$ & $\mathrm{H}_{3} \mathrm{C}_{-}$ & \\
\hline
\end{tabular}

\subsection{Characterization}

The crystalline phase of mill scale was determined by X-ray powder diffraction with monochromated $\mathrm{Cu} \mathrm{Ka}$ radiation.

\subsection{Photodecomposition Experiments of MB}

The experiments were carried out by adding varying amounts of mill scale to $100 \mathrm{ml}$ of aqueous solution containing $\mathrm{MB}$ and $\mathrm{H}_{2} \mathrm{O}_{2}$ or oxalic acid. Before photo reaction, the suspension was magnetically stirred in the dark for half an hour to establish absorption-desorption equilibrium. The various aqueous suspensions were then illuminated by UV or solar illumination with magnetic stirring. The photodegradation was carried out under two $8 \mathrm{~W}$ UV lamps with the main emission at $365 \mathrm{~nm}$. Solar illumination of the magnetically stirred sample suspension was carried out in a room beside a window. At a given time of intervals, the analytical samples were withdrawn from the suspension and then stored in the dark for needed analysis. The absorbance spectrum was determined with a UV-vis spectrophotometer (optizen 3220UV, Korea) and degradation of $\mathrm{MB}$ was monitored by recording the absorbance at $\lambda_{\max }=664 \mathrm{~nm}$ as a function of illumination time. The percent decolorization and rate constant values were calculated as follows [14-15]:\%Decolorization $=100 \mathrm{x}$ $\left(\mathrm{C}_{\mathrm{o}}-\mathrm{C}_{\mathrm{t}}\right) / \mathrm{C}_{\mathrm{o}}$, Rate constant, $\mathrm{k}=\left(\operatorname{Ln}\left(\mathrm{C}_{\mathrm{t}} / \mathrm{C}_{\mathrm{o}}\right)\right) /(-\mathrm{t})$; where $\mathrm{C}_{0}$ is the initial concentration of dye, and $\mathrm{C}_{\mathrm{t}}$ is the concentration of dye at reaction time $\mathrm{t}(\mathrm{min})$.

The photodecomposition experiments were performed under the following experimental conditions, $\mathrm{MB}$ concentration $\left(\mathrm{C}_{\mathrm{o}}\right)=0.01-0.1 \mathrm{mM}$, mill scale content $=$ $0.1-1.3 \mathrm{~g} / 100 \mathrm{~mL}$, oxalic acid concentration $0.5-3.0 \mathrm{mM}$ and $\mathrm{H}_{2} \mathrm{O}_{2}$ concentration 1-4 mL/100mL aqueous suspension.

\section{Result and Discussion}

\subsection{XRD and Phases of Mill Scale}

The crystalline phase of mill scale, determined by X-ray powder diffraction shown in figure 1 . The phases found were wustite, magnetite, \& hematite.

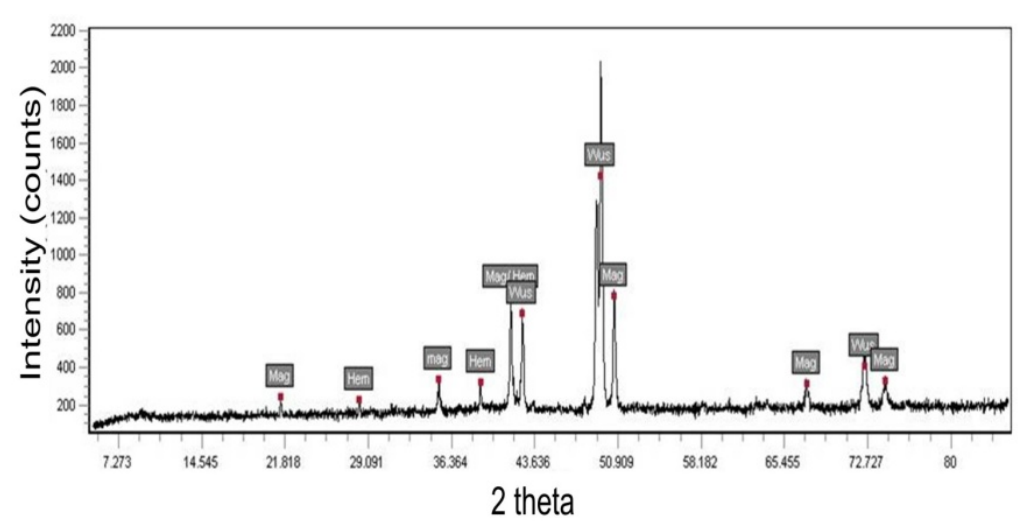

Figure 1. XRD pattern of mill scale 


\subsection{Effect of Variables on MB Degradation}

Figure 2 shows the MB degradation under different experimental conditions. Curve a represents MB degradation in presence of $1.0 \mathrm{mM}$ oxalic acid and UV light . Degradation was only $11 \%$ at this condition. Curve $b$ represents the degradation experiment under UV irradiation only and it was $12.5 \%$. The degradation increased to $20 \%$ when experiment was carried out in presence of $2 \mathrm{ml} \mathrm{H}_{2} \mathrm{O}_{2}$ (curve c).

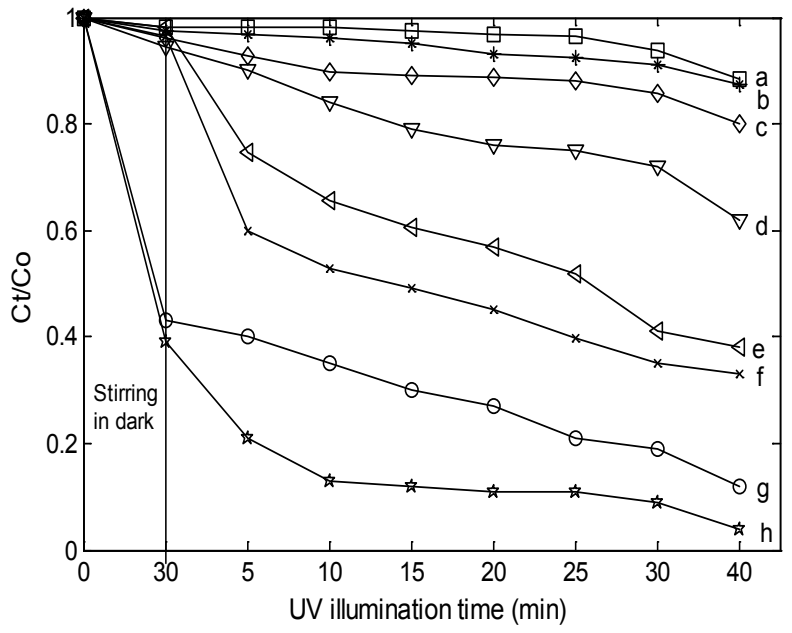

Figure 2. Degradation of $0.05 \mathrm{mM} M B$ under different condition (a) 1.0 $\mathrm{mM} \mathrm{OA} \mathrm{(b)} \mathrm{UV} \mathrm{(c)} 2 \mathrm{~mL} \mathrm{H}_{2} \mathrm{O}_{2}$ (d) $\mathrm{UV}+0.8 \mathrm{gm}$ mill scale (e) $\mathrm{UV}+1 \mathrm{mM}$ oxalic Acid (f) $\mathrm{UV}+2 \mathrm{mLH}_{2} \mathrm{O}_{2}(\mathrm{~g}) \mathrm{UV}+1 \mathrm{mM}$ oxalic Acid +0.8 gm mill scale (h) $\mathrm{UV}+2 \mathrm{mLH}_{2} \mathrm{O}_{2}+0.8 \mathrm{~g}$ mill scale

Then MB degradation increased to $38 \%$ under UV and in presence of $0.8 \mathrm{~g}$ mill scale (curve d). The degradation of MB was $61.9 \%$ under UV light irradiation and $1 \mathrm{mM}$ oxalic acid. Another experiment showed degradation of $67 \%$ under UV irradiation and in presence of $2 \mathrm{ml} \mathrm{H}_{2} \mathrm{O}_{2}$ (curve f). Degradation was found to be $88 \%$ under UV light and $0.8 \mathrm{gm}$ mill scale with $1 \mathrm{mM}$ oxalic acid (curve g). Finally when $2.0 \mathrm{~mL} \mathrm{H}_{2} \mathrm{O}_{2}, 0.8 \mathrm{~g}$ mill scale and UV irradiation were used combined, the removal percentage of MB significantly increased upto $98 \%$ (curve h). Thus it was observed that either the combination of UV light, mill scale and $\mathrm{H}_{2} \mathrm{O}_{2}$ or the combination of UV light, mill scale and $\mathrm{OA}$ are required for complete degradation of MB.

\subsection{Effect of Mill Scale Content on MB Degradation}

A set of experiments were carried out to observe the dependence of MB photodegradation with the mill scale variation under UV light irradiation in presence of $\mathrm{H}_{2} \mathrm{O}_{2}$ (photo-Fenton) and $\mathrm{OA}$ (photo-ferrioxalate system) per $100 \mathrm{ml}$ aqueous solution. Mill scale content was taken as $0.1 \mathrm{~g}$, $0.3 \mathrm{~g}, 0.5 \mathrm{~g}, 0.8 \mathrm{~g}, 1.0 \mathrm{~g}$ and $1.3 \mathrm{~g}$ for $100 \mathrm{~mL}$ of solution. The corresponding rate constant values for both of these experiments are shown in figure 3 .

Optimum mill scale content was found $0.8 \mathrm{~g}$ for photo Fenton and $0.5 \mathrm{~g}$ for photo-ferrioxalate system under UV illumination. When the Fe ion concentration is too low, e.g.,
$0.1 \mathrm{~g} / 100 \mathrm{ml}$, the decolorization rate is slow because there are not sufficient ions available for dye degradation. With increasing mill scale content upto $0.8 \mathrm{~g}$ in case of photo-Fenton and $0.5 \mathrm{~g}$ in case of photo-ferrioxalate, the decolorization rate also increased. Because when Fe ion concentration increases, the catalytic effect also accordingly increases and when its concentration become higher, a great amount of $\mathrm{Fe}$ ion is produced. $\mathrm{Fe}$ ion undergoes a reaction with hydroxyl ions to form $\mathrm{Fe}(\mathrm{OH})^{2+}$ which in turn produces more ${ }^{\circ} \mathrm{OH}$ radicals (Eqs. 1-3) $[16,17]$. This ${ }^{\circ} \mathrm{OH}$ radical increases the rate of decomposition.

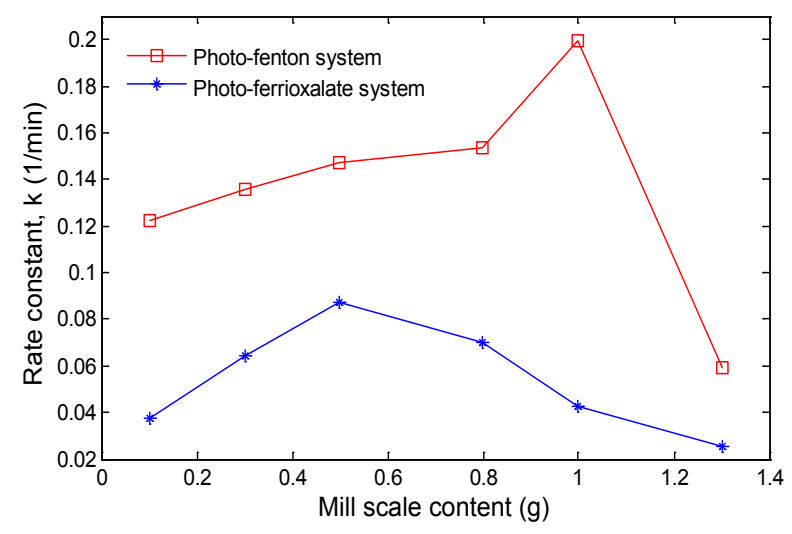

Figure 3. MB photodecomposition rate constant (k) under various mill scale contents.

On the other hand, when the iron powder concentration is too high, e.g., $1.3 \mathrm{~g} / 100 \mathrm{~mL}$, the reaction suspension became more turbid with excessive oxide loading, and this suppressed the penetration of UV light and hence photoactivated volume of suspension decreases. This in turn decreased the formation of ${ }^{\circ} \mathrm{OH}$ radicals, lowering the photodecomposition ability. Thus it can be said that higher dose of catalyst may not be useful both in view of aggregation as well as reduced irradiation field due to light scattering .

\subsection{Effect of $\mathrm{H}_{2} \mathrm{O}_{2}$ Variation on MB Degradation in Photo Fenton System}

In a photo-Fenton-based system, the oxidant concentration is a key factor that can significantly influence the degradation of organics. The $\mathrm{H}_{2} \mathrm{O}_{2}$ concentration is directly related to the number of hydroxyl radicals generated, and thus to the performance achieved.

Figure 4 displays the effect of the hydrogen peroxide dosage, in this case for decolorizing MB over mill scale. $\mathrm{MB}$ degradation was carried out with $1 \mathrm{ml}, 2 \mathrm{ml}$ and $4 \mathrm{ml} \mathrm{H}_{2} \mathrm{O}_{2}$. The observed effect of the $\mathrm{H}_{2} \mathrm{O}_{2}$ concentration was clear: the higher the $\mathrm{H}_{2} \mathrm{O}_{2}$ concentration, the faster the colour removal. As it can be observed from figure 4, using concentrations of $\mathrm{H}_{2} \mathrm{O}_{2}=1 \mathrm{ml}$, colour degradation rate was $0.044,0.041$, 0.020 for $0.01,0.05,0.1 \mathrm{mM} \mathrm{MB}$ respectively. and it was increased to $0.058,0.043,0.025$ when $\mathrm{H}_{2} \mathrm{O}_{2}=2 \mathrm{ml}$ and finally it was 0.103 and 0.057 with $4 \mathrm{ml} \mathrm{H}_{2} \mathrm{O}_{2}$ when 0.05 and 
$0.1 \mathrm{mM}$ MB used respectively. But the result was undefined when $0.01 \mathrm{mM}$ MB was used in this case of $4 \mathrm{ml} \mathrm{H}_{2} \mathrm{O}_{2}$. This is due to the fact that at higher $\mathrm{H}_{2} \mathrm{O}_{2}$ concentrations scavenging of $\mathrm{HO}^{\circ}$ radicals will occur, as expressed by the following equations $[18,19]$ :

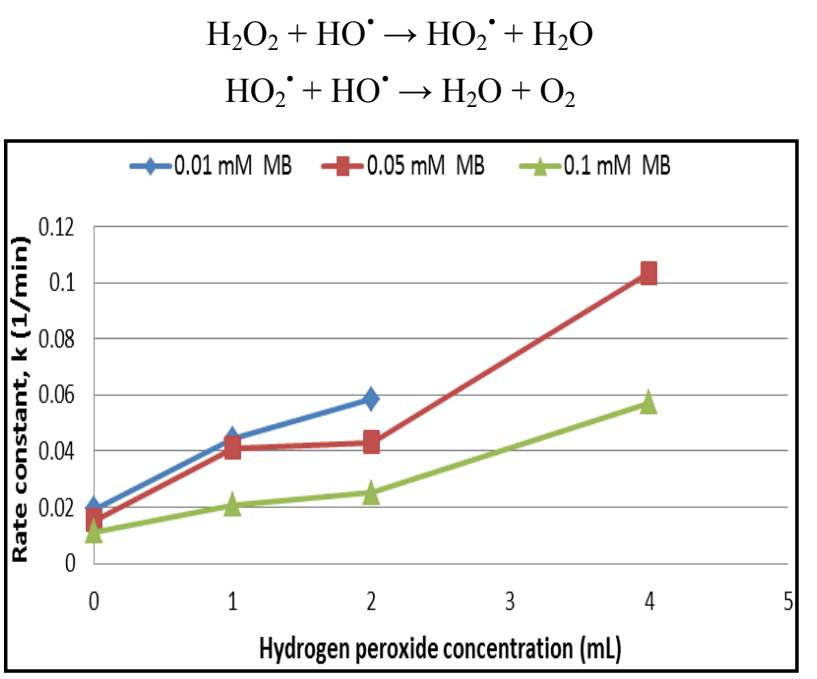

Figure 4. Photodecomposition rate constants $(\mathrm{k})$ of various concentration of $\mathrm{MB}$ for $\mathrm{H}_{2} \mathrm{O}_{2}(1,2,4) \mathrm{ml}$ concentrations in the presence of $0.8 \mathrm{~g}$ mill scale under UV illumination

It is important to remark that $\mathrm{HO}_{2}{ }^{\circ}$ is less reactive than $\mathrm{HO}^{\circ}$, and thus an increased amount of hydrogen peroxide has a diminishing return on the reaction rate [20]. From figure 4 it was clear that degradation of $\mathrm{MB}$ was increased with increasing $\mathrm{H}_{2} \mathrm{O}_{2}$ concentration and best photo-degradation was possible at $4 \mathrm{~mL}_{2} \mathrm{O}_{2}$. But due to very fast degradation of $\mathrm{MB}$ it was difficult to determine the rate constant for low concentration of MB. So, $2 \mathrm{~mL} \mathrm{H}_{2} \mathrm{O}_{2}$ per $100 \mathrm{~mL}$ solution was used for further experiment.

\subsection{Effect of Initial Concentration of Dye on MB Degradation}

After optimizing the catalyst dose, the photocatalytic degradation of $\mathrm{MB}$ was carried out by varying the initial concentrations of the dye from $0.01-0.1 \mathrm{mM}$. Here, various concentrations of MB $(0.01 \mathrm{mM}, 0.05 \mathrm{mM}$ and $0.1 \mathrm{mM})$ were decomposed in presence of $2 \mathrm{~mL} \mathrm{H}_{2} \mathrm{O}_{2}$ under UV illumination with different amount of mill scale $(0.3 \mathrm{~g}, 0.8 \mathrm{~g}$ and $1.3 \mathrm{~g} / 100 \mathrm{~mL}$ solution) as shown in figure 5 . From the results it can be seen that for all cases decomposition rate decreased with increasing concentration of MB. When $0.3 \mathrm{~g}$ mill scale was used, the rate constant values were $0.19,0.10$ and 0.08 for $0.01,0.05$ and $0.1 \mathrm{mM} \mathrm{MB}$ respectively. When $0.8 \mathrm{~g}$ mill scale was used the rate constant values were 0.35 , 0.27 and 0.10 for $0.01,0.05$ and $0.1 \mathrm{mM} \mathrm{MB}$ respectively. And when $1.3 \mathrm{~g}$ mill scale was used the rate constant values were $0.28,0.13$ and 0.08 for $0.01,0.05$ and $0.1 \mathrm{mM} \mathrm{MB}$ respectively.

\subsection{Effect of OA Variation on MB Degradation in}

\section{Photo-Ferrioxalate System}

A series of experiments were performed to examine the effect of the initial oxalic acid concentration under the following conditions; $\mathrm{MB}$ concentration $=0.05 \mathrm{mM}$, mill scale content $=0.5 \mathrm{~g} / 100 \mathrm{~mL}$ and UV light illumination. The degradation of $\mathrm{MB}$ concentration at various oxalate concentrations are shown in figure 6 as a function of the UV illumination time for oxalic acid concentrations of $0.5,1,2$ and $3 \mathrm{mM}$, respectively. This result clearly shows the enhancement of MB photodecomposition in oxalate solution. Previously it was shown that (figure 2) without OA the degradation was $38 \%$ in presence of (UV $+0.8 \mathrm{~g}$ mill scale). The optimal oxalate concentration is $1 \mathrm{mM}$ under these experimental conditions. Balmer and Sulzberger [14] reported that $\mathrm{Fe}^{3+}$ is present mainly as $\left[\mathrm{Fe}(\mathrm{III})\left(\mathrm{C}_{2} \mathrm{O}_{4}\right)_{2}\right]^{-}$ and $\left[\mathrm{Fe}(\mathrm{III})\left(\mathrm{C}_{2} \mathrm{O}_{4}\right)_{3}\right]^{3-}$ in the $\mathrm{Fe}(\mathrm{III})$-oxalate system when the concentration of oxalate is $>0.18 \mathrm{mM}$. On this basis, $\mathrm{Fe}(\mathrm{III})\left(\mathrm{C}_{2} \mathrm{O}_{4}\right)_{2}{ }^{-}$and $\mathrm{Fe}(\mathrm{III})\left(\mathrm{C}_{2} \mathrm{O}_{4}\right)_{3}{ }^{3-}$ are thought to be formed under the present experimental conditions, and may be much more efficiently photolyzed than other $\mathrm{Fe}^{3+}$ species, greatly enhancing MB photodecomposition in the presence of oxalic acid. However, any excess oxalic acid will occupy the adsorption sites on the surface of mill scale, and will also compete with $\mathrm{MB}$ in the photodecomposition reaction.

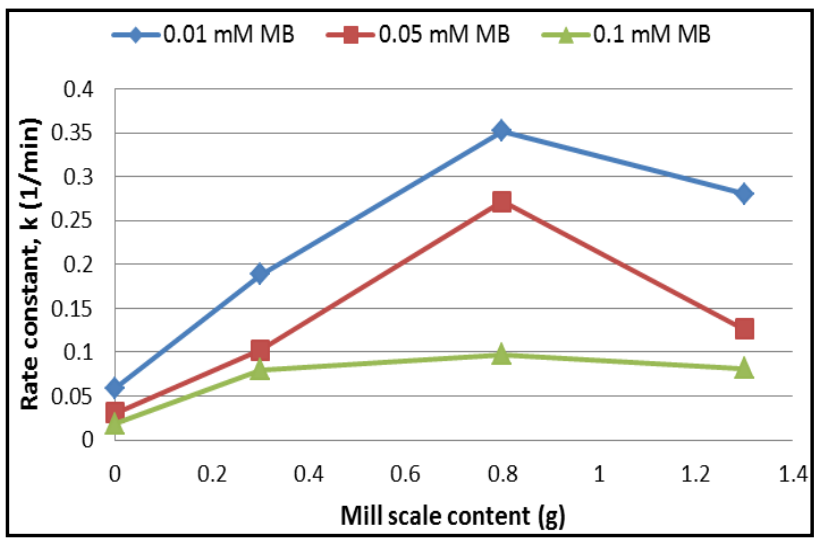

Figure 5. Photodecomposition rate constants (k) of various concentration of $\mathrm{MB}$

\subsection{Effect of Solar/UV Irradiation on MB Degradation}

The photocatalytic degradation of MB using mill scale as photocatalyst and solar/UV irradiation as light source has been carried out under $2 \mathrm{~mL} \mathrm{H}_{2} \mathrm{O}_{2}$ concentration per $100 \mathrm{~mL}$ solution and the results are presented in figure 7. About $95 \%$ degradation is achieved within 60 minute under UV irradiation whereas same degradation requires more than 120 minute in solar irradiation of MB dye. The difference in the rate of degradation is attributed to difference in the input energy. The energy of UV irradiation is large compared to band gap energy of the catalysts. Hence, the problem of electron-hole recombination is not fully but largely avoided with UV source.

But in sunlight only $5 \%$ of the total radiation possesses the 
optimum energy [21] for the band gap excitation of electrons. Hence, the percentage degradation is found to be less in solar radiation. Although sunlight has only $5 \%$ of optimum energy for photocatalytic excitation and ultimately degradation of dyes, it could be safe and cost effective source. UV source is not only hazardous but also expensive because of large input of electric power to generate UV irradiation. In tropical countries intense sunlight is available throughout the years and, hence, it could be effectively used for photocatalytic degradation of pollutants in wastewater. In case of large surface demanding photocatalytic degradation, sunlight would be the ultimate source. Moreover there is no material deterioration in case that sunlight is used as a radiation source. But UV light source may effect the catalyst decomposition [22].

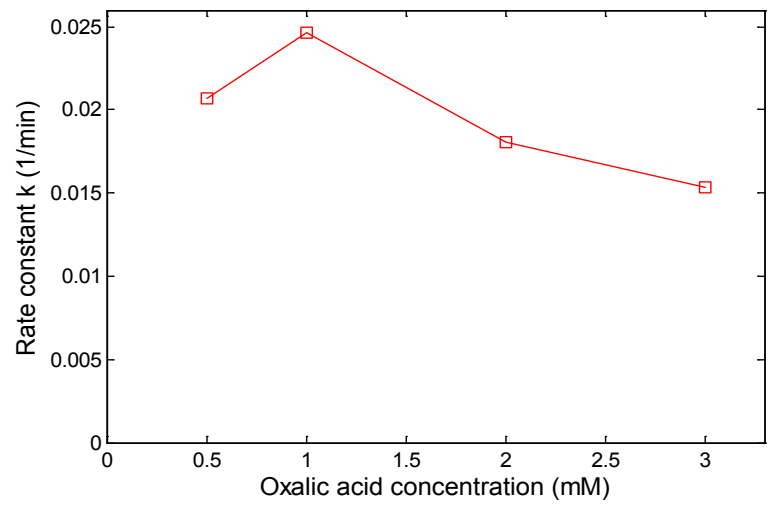

Figure 6. MB photodecomposition rate constants, $\mathrm{k}$ in various oxalic acid concentrations

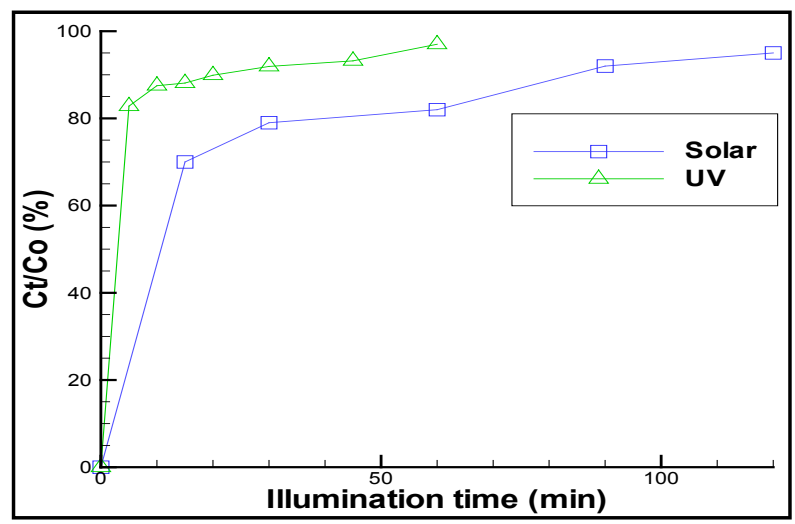

Figure 7. Effect of solar/UV light source on the degradation of $\mathrm{MB}$

\section{Conclusions}

Experimental results indicated that the decolorization of $\mathrm{MB}$ is facilitated in the presence of mill scale. The combination of mill scale, hydrogen peroxide or oxalic acid and light illumination (UV or Solar) is essential for the photodecomposition of MB. The optimum mill scale content was found to be $0.8 \mathrm{~g} / 100 \mathrm{ml}$ solution in presence of $\mathrm{H}_{2} \mathrm{O}_{2}$ and $0.5 \mathrm{~g} / 100 \mathrm{ml}$ solution in presence of OA under UV illumination. Degradation of $\mathrm{MB}$ was increased with increasing $\mathrm{H}_{2} \mathrm{O}_{2}$ concentration and decreased with increasing dye concentration. Optimum oxalic acid concentration was $1 \mathrm{mM}$ for the degradation of MB. The MB photodecomposition was found higher under UV than solar illumination. Among the Photo-Fenton and photo-ferrioxalate system, photo-Fenton route showed the highest degradation rate.

Last but not the least, it can be concluded that mill scale can effectively be used as a photocatalyst for the degradation of dyes.

\section{Acknowledgements}

The authors are grateful to Ministry of Science and Technology, Government of the Peoples Republic of Bangladesh for providing fund and Bangladesh University of Engineering and Technology for providing facilities to carry out this research work.

\section{REFERENCES}

[1] Y. M. Slokar, A. M. Le Marechal, "Methods of decoloration of textile waste waters", Dyes and Pigments, Vol. 37, pp. 335-339 (1998).

[2] F. Gökçen, T. A. Özbelge, "Pre-ozonation of aqueous azo dye (Acid Red-151) followed by activated sludge process", Journal of Chemosphere Engineering, Vol. 123, pp. 109-115 (2006).

[3] R. Jain, S. Varshney, S. Sikarwar, "Electrochemical techniques for the removal of Reactofix Golden Yellow 3 RFN from industrial wastes", Journal of Colloids and Interface Science, Vol. 313, pp. 248 - 253 (2007).

[4] S. A. Ong, E. Toorisaka, M. Hirata, T. Hano, "Granular activated carbon-bio film configured sequencing batch reactor treatment of C.I. Acid Orange 7", Dyes and Pigments, Vol.76, pp. 142-146 (2008).

[5] S. M. Tomaszewska, A. W. Morawski, "Photodegradation of azo dye Acid Red 18 in a quartz labyrinth flow reactor with immobilized TiO2 bed", Dyes and Pigments, Vol. 75, pp. 6066 (2007).

[6] Y. Badr, Mahmoud, "Photocatalytic degradation of methyl orange by gold silver nano-core/shell nano-shell", Journal of Physics. Chemosphere Solution, Vol. 68, pp. 413-419 (2007).

[7] J Feng, X Hu, Yu e PL, HY Zhu, L u GQ, "Discoloration and mineralization of Reactive Red HE-3B by heterogeneous photo-Fenton reaction", Water Resourse, Vol. 37, pp. 3776-84 (2003).

[8] M Litter, C Emilio, W Jardim, H Mansilla, "EDTA destruction using the solar ferrioxalate advanced oxidation technology (AOT) comparison with solar photo-Fenton treatment", Journal of Photochemistry and Photobiology A: Chemistry, Vol. 151, pp. 121 -7 (2002).

[9] F Gulshan, S Yanagida, Y Kameshima, T Isobe, A Nakajima, 
K Okada, Various factors affecting photodecomposition of methylene blue by iron oxides in an oxalate solution", Water research, Vol.44, pp.2876-2884(2010).

[10] S.C. Pillai, P. Periyat, R. George, D.E. McCormack, M.K. Seery, H. Hayden, J. Colreavy, D. Corr, S.J. Hinder, "Synthesis of High-Temperature Stable Anatase TiO2 Photocatalyst" The Journal of Physical Chemistry C, Vol. 111, pp. 1605-1611 (2007).

[11] T.L. Thompson, J.T. Yates Jr., Surface Science Studies of the Photoactivation of TiO2New Photochemical Processes, Chemical Reviews, Vol. 106 (10), pp. 4428-4453 (2006).

[12] Y. Shiraishi, N. Saito, T. Hirai, "Adsorption-driven photocatalytic activity of mesoporous titanium dioxide", Journal of the American Chemical Society, Vol. 127(37), pp. 12820-2 (2005).

[13] Y. Du, J. Rabani, "The Measure of TiO2 Photocatalytic Efficiency and the Comparison of Different Photocatalytic Titania", Journal of Physical Chemistry B, Vol. 107, pp. 11970 -11978 (2003).

[14] M. E. Balmer, B Sulzberger, "Attrazine degradation in irradiated iron/oxalate systems: effect of $\mathrm{pH}$ and oxalate", Environmental Science and Technology, Vol. 33, pp. 2418-2424 (1999).

[15] S K Kansal, N Kaur and S Singh, "Photocatalytic Degradation of Two Commercial Reactive Dyes in Aqueous Phase Using Nanophotocatalysts", Nanoscale Research Letters, Vol. 4, No. 7, pp. 709-716 (2009).
[16] X Xu, H Zhao, Y D W. Wang, "2-Chlorophenol oxidation kinetic by photo-assisted Fenton process", Journal of Environmental Science, Vol. 15, pp. 475-81 (2003).

[17] Y Zhao, X K Wang, Y J GP and X C Gao, "Photochemical degradation of dimethyl phthalate by Fenton reagent", Journal of Photochemistry and Photobiology A: Chemistry,, Vol. 161, pp. 215-20 (2004).

[18] W. Najjar, S. Azabou, S. Sayadi, A. Ghorbel, "Catalytic wet peroxide photo-oxidation of phenolic olive oil mill wastewater contaminants: Part I. Reactivity of tyrosol over (Al-Fe) PILC" Applied Catalysis B: Environmental, Vol. 74, Issues 1-2, pp. 11-18 (2007).

[19] Q. Chen, P. Wu, Y. Li, N. Zhu, Z. Dang, "Heterogeneous photo-Fenton photodegradation of reactive brilliant orange $\mathrm{X}-\mathrm{GN}$ over iron-pillared montmorillonite under visible irradiation" Journal of Hazardous Materials, Vol. 168 (2-3) pp. 901-908 (2009)

[20] J. Herney-Ramirez, Miguel A. Vicente, Luis M. Madeira, Heterogeneous photo-Fenton oxidation with pillared clay-based catalysts for wastewater treatment: A review, Applied Catalysis B: Environmental 98 (2010) 10-26)

[21] P.Maruthamuthu, in: V. Murugesan (Ed.), Photocatalytic Decomposition of Pollutants, National Workshop on Industrial Wastewater Treatment by Semiconductor Photocatalysis, Anna University, Chennai, India, 1995.

[22] J. Domenech, A. Prieto, "Stability of zinc oxide particles in aqueous suspensions under UV illumination", The Journal of Physical Chemistry, Vol. 90 (6), pp. 1123-1126 (1986). 